\title{
Visceral Obesity and Its Shared Role in Cancer and Cardiovascular Disease: A Scoping Review of the Pathophysiology and Pharmacological Treatments
}

\author{
Erika Aparecida Silveira ${ }^{1,2, *} \mathbb{0}$, Golnaz Vaseghi ${ }^{3}$, Annelisa Silva de Carvalho Santos ${ }^{2,4} \mathbb{C}_{\text {, }}$
} Nathalie Kliemann ${ }^{5}$, Farzad Masoudkabir ${ }^{6,7}$, Matias Noll ${ }^{2,8}{ }^{(\mathbb{C}}$, Noushin Mohammadifard ${ }^{9}{ }^{(}$, Nizal Sarrafzadegan ${ }^{10,11, *(1)}$ and Cesar de Oliveira ${ }^{1}$

1 Department of Epidemiology \& Public Health, Institute of Epidemiology \& Health Care, University College London, London WC1E 6BT, UK; c.oliveira@ucl.ac.uk

2 Postgraduate Program in Health Sciences, Faculty of Medicine, Federal University of Goiás, Goiânia 74690-900, Goiás, Brazil; annelisa.nut@gmail.com (A.S.d.C.S.); matias.noll@ifgoiano.edu.br (M.N.)

3 Applied Physiology Research Center, Cardiovascular Research Institute, Isfahan University of Medical Sciences, Isfahan 8158388994, Iran; golnazvaseghi@yahoo.com

4 United Faculty of Campinas, Goiânia 74525-020, Goiás, Brazil

5 Nutritional Epidemiology Group, Nutrition and Metabolism Section, International Agency for Research on Cancer, World Health Organization, 69372 Lyon, France; kliemannn@fellows.iarc.fr

6 Cardiac Primary Prevention Research Center, Tehran Heart Center, Tehran University of Medical Sciences, Tehran 1416753955, Iran; farzad.masoudkabir@gmail.com

7 Department of Cardiology, Tehran Heart Center, Tehran University of Medical Sciences, Tehran 1411713138, Iran

8 Instituto Federal Goiano, Ceres 76300-000, Goiás, Brazil

9 Hypertension Research Center, Cardiovascular Research Institute, Isfahan University of Medical Sciences, Isfahan 8158388994, Iran; nmohammadifard@gmail.com

10 Isfahan Cardiovascular Research Center, Cardiovascular Research Institute, Isfahan University of Medical Sciences, Isfahan 8158388994, Iran

11 School of Population and Public Health, Faculty of Medicine, University of British Columbia, Vancouver, BC V6T 1Z3, Canada

* Correspondence: erikasil@terra.com.br (E.A.S.); nsarrafzadegan@gmail.com (N.S.)

Received: 31 August 2020; Accepted: 12 November 2020; Published: 27 November 2020

\begin{abstract}
The association between obesity, cancer and cardiovascular disease (CVD) has been demonstrated in animal and epidemiological studies. However, the specific role of visceral obesity on cancer and CVD remains unclear. Visceral adipose tissue (VAT) is a complex and metabolically active tissue, that can produce different adipokines and hormones, responsible for endocrine-metabolic comorbidities. This review explores the potential mechanisms related to VAT that may also be involved in cancer and CVD. In addition, we discuss the shared pharmacological treatments which may reduce the risk of both diseases. This review highlights that chronic inflammation, molecular aspects, metabolic syndrome, secretion of hormones and adiponectin associated to VAT may have synergistic effects and should be further studied in relation to cancer and CVD. Reductions in abdominal and visceral adiposity improve insulin sensitivity, lipid profile and cytokines, which consequently reduce the risk of CVD and some cancers. Several medications have shown to reduce visceral and/or subcutaneous fat. Further research is needed to investigate the pathophysiological mechanisms by which visceral obesity may cause both cancer and CVD. The role of visceral fat in cancer and CVD is an important area to advance. Public health policies to increase public awareness about VAT's role and ways to manage or prevent it are needed.
\end{abstract}


Keywords: visceral obesity; cancer; cardiovascular disease; pathophysiological mechanisms; pharmacological treatments

\section{Introduction}

Visceral obesity is a type of body fat deposition in the upper part of the body and within the abdominal cavity. This adipose tissue is located near several organs, such as the liver, stomach and intestines and it can build up in the arteries. Visceral fat is sometimes known as "active fat" because it can actively increase the risk of adverse health problems. Visceral adipose tissue (VAT) is a complex and metabolically active tissue, which can produce different adipokines and hormones responsible for endocrine-metabolic comorbidities. It is associated with increased adipocytokine production, proinflammatory activity and altered blood lipids levels as well as with decreased HDL cholesterol [1].

There is growing consensus that visceral obesity represents an important risk factor for diabetes, cardiovascular disease (CVD) and different types of cancers [2-5] such as esophagus, pancreas, colorectum, breast, endometrium, kidney and prostate [6,7]. A growing body of evidence suggests an overlap of the epidemiological risk factors of both CVD and cancer $[5,8]$. In fact, the association between obesity, cancer and CVD has been established in a multitude of animal and epidemiological studies $[5,8]$. Research on this topic is now focusing on the role of VAT on carcinogenesis and development of CVD, which may involve alterations in immunological, metabolic and endocrinal pathways.

Therefore, this review aims to highlight the potential shared disease pathways linking visceral obesity to cancer and CVD. In addition, we discuss the shared pharmacological treatments that may mitigate the risk of both conditions.

\section{Pathophysiological Evidence of the Shared Role of Visceral Obesity in the Occurrence of Cancer and CVD}

Figure 1 summarizes the main pathophysiological mechanisms shared in the development of CVD and cancer. In Table 1, we present a summary of the risk factors in visceral obesity, cardiovascular disease and cancer.

Table 1. Risk factors in visceral obesity, cardiovascular disease and cancer.

\begin{tabular}{|c|c|c|c|}
\hline Risk factor & Visceral Obesity & Cardiovascular Disease & Cancer \\
\hline Adipokines & $\begin{array}{l}\text { Adipocytes cell } \\
\text { differentiation }\end{array}$ & $\begin{array}{l}\text { Effect on nitric oxide synthase } \\
\text { (NOS) and ROS, peripheral } \\
\text { arterial dysfunction, hypertension, } \\
\text { dyslipidemia }\end{array}$ & $\begin{array}{l}\text { Proliferation and inhibits } \\
\text { p53-dependent apoptosis }\end{array}$ \\
\hline $\begin{array}{l}\text { Insulin and insulin like } \\
\text { growth hormone }\end{array}$ & Metabolic dysfunction, & $\begin{array}{c}\text { Decrease eNOS activation and NO } \\
\text { production, which leads to } \\
\text { entrance of inflammation to } \\
\text { plaque }\end{array}$ & $\begin{array}{l}\text { Promote cell proliferation, } \\
\text { differentiation and } \\
\text { protection from apoptosis }\end{array}$ \\
\hline Sex hormones & Estrogen signaling & $\begin{array}{l}\text { Plasma HDL cholesterol levels are } \\
\text { significantly higher and fasting } \\
\text { plasma glucose concentrations }\end{array}$ & Increase aromatase activity \\
\hline $\begin{array}{l}\text { Fibroblast growth } \\
\text { factor }\end{array}$ & Inflammation & $\begin{array}{l}\text { Cardiac hypertrophy through the } \\
\text { activation of FGF receptor }\end{array}$ & $\begin{array}{l}\text { Transformation of } \\
\text { epithelial cell }\end{array}$ \\
\hline $\begin{array}{l}\text { Alterations in DNA } \\
\text { methylation }\end{array}$ & $\begin{array}{l}\text { Long interspersed nuclear } \\
\text { element activation }\end{array}$ & $\begin{array}{l}\text { Metabolic syndrome, Ischemic } \\
\text { heart disease }\end{array}$ & Cell proliferation \\
\hline
\end{tabular}




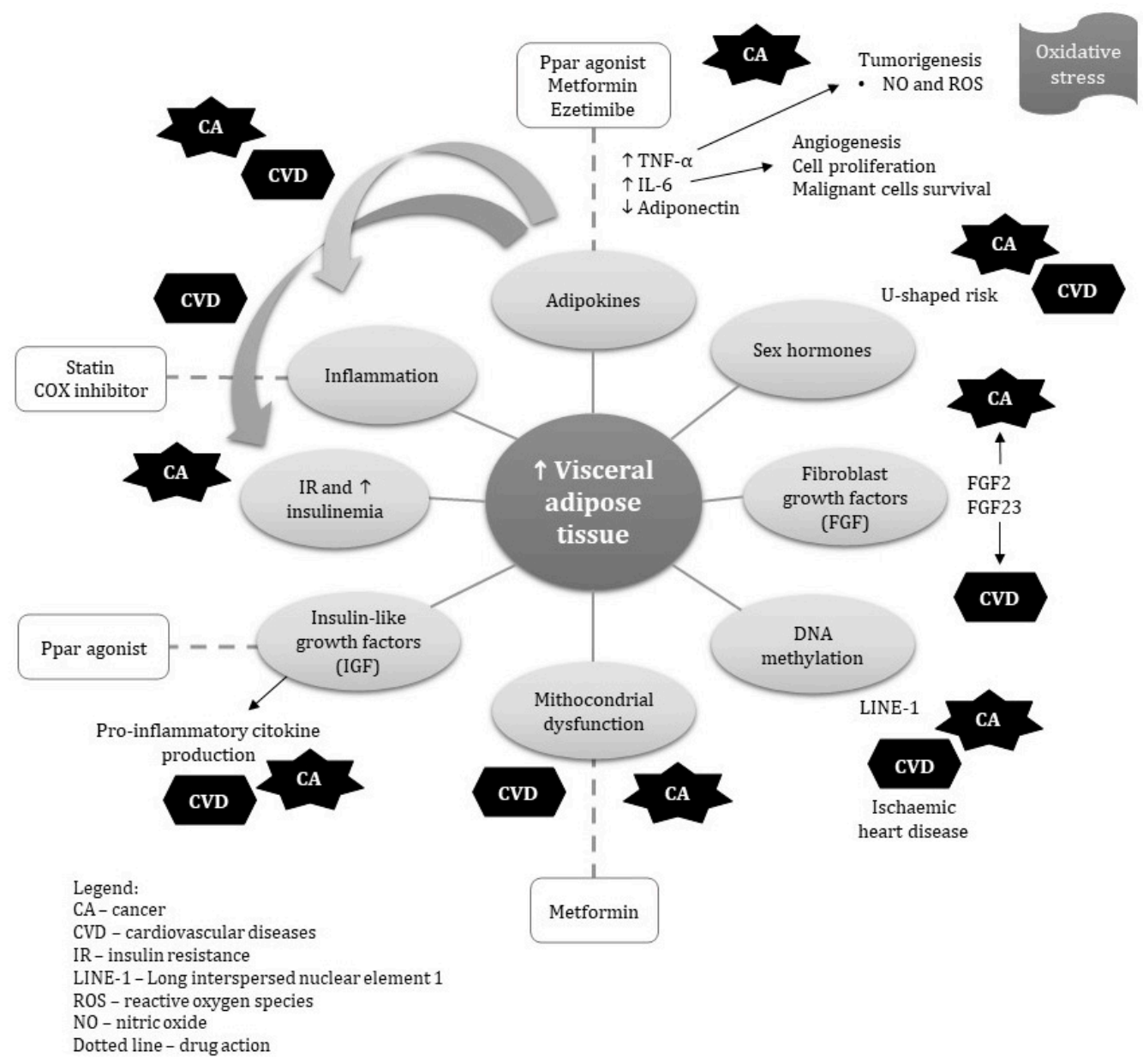

Figure 1. Summary of the main pathophysiological mechanisms shared in the development of cardiovascular disease (CVD) and cancer.

\subsection{Inflammation}

Increases in VAT cause adipose dysfunction and induce chronic local inflammation, which mediates most obesity-related complications [9]. The inflammatory process of the adipose tissue is characterized by the infiltration of classically activated M1 macrophages, leading to the production of reactive oxygen species (ROS) and release of pro-inflammatory cytokines such as interleukin 6 (IL-6) and tumor necrosis factor- $\alpha($ TNF- $\alpha)[10]$.

Chronic inflammation has been linked to the development and progression of cardiovascular diseases [11] and several cancers [12,13], suggesting a shared pathophysiological role [14]. Regarding CVD, a chronic low-grade inflammatory environment is associated with the development of metabolic syndrome, type 2 diabetes, hypertension and dyslipidemia, which are linked to increased risk of cardiovascular events [11]. As for cancer, chronic inflammation is central for its development and progression, since inflammatory cells and mediators promote angiogenesis and sustain proliferative signaling [9,15-17]. Excessive caloric intake results in a dynamic response of adipose tissue via adipocyte hypertrophy and hyperplasia [18]. The rapid expansion of adipose tissue in obesity results in cellular hypoxia and activates hypoxia-inducible factor 1- $\alpha$ (HIF $1 \alpha)$ [19]. This, in turn, increases the expression of IL- 6 and leptin, decreases adiponectin production and mediates the attraction of macrophages into the adipose tissue [20,21]. It has been reported that due to enhanced basal lipolysis [22], leakage of free fatty acids (FFAs) is increased in hypertrophic adipocytes. The released FFAs promote inflammation through binding to toll-like receptors 2 and 4 which results in activation of nuclear factor-kappa B (NF-KB) and c-Jun N-terminal kinase (JNK) signaling pathways [23]. The activation of aforementioned pathways increases the synthesis and secretion of pro-inflammatory cytokines such as IL-6. 
Along with their role in chronic inflammation, IL- 6 and TNF- $\alpha$ also contribute to other mechanistic effects on cancer development. Regarding IL-6, this adipocytokine stimulates angiogenesis, promotes cell proliferation, increases survival of malignant cells and inhibits cancer cell apoptosis, for example, in colon cancer $[24,25]$. As for the TNF- $\alpha$, it is involved in all stages of tumorigenesis. TNF- $\alpha$ stimulates the growth and survival of malignant cells, promotes angiogenesis, invasion and migration of malignant cells, and suppress cytotoxic T lymphocytes and activated macrophages [26]. Moreover, TNF- $\alpha$ plays an important role in the initiation of tumors by stimulating the production of nitric oxide (NO) and ROS. ROS are well-known genotoxins [27], and it has been demonstrated that $\operatorname{Trp} 53^{-/}$in mice maintained in relatively hypoxic conditions $\left(10 \% \mathrm{O}_{2}\right)$ have a significantly reduced level of tumorigenesis and improved survival compared to Trp $53^{-/-}$mice maintained in standard atmospheric conditions $\left(21 \% \mathrm{O}_{2}\right)$ [28]. Moreover, ROS trigger potentially oncogenic signal transduction cascades including mitogen-activated protein kinase (MAPK) and epidermal growth factor receptor (EGFR) signaling [29].

\subsection{Adipokines}

Adipokines are hormones secreted by the adipose tissue, such as adiponectin and leptin that regulate systemic metabolism and inflammation. They have been suggested as a link between obesity and other disorders such as cardiovascular disease and cancer [9]. Adiponectin has autocrine activity that results in adipocytes cell differentiation. In adipocytes, some factors such as sterol regulatory element-binding protein (SREBP)-1c promotes adipogenesis and enhances lipid content [30]. Excess weight gain may promote profound changes in the adipokines production increasing the risk of cancer and cardiovascular disease [9].

Adiponectin is a protein hormone with vasoprotective properties [31] and antineoplastic activity [32]. Clinical studies indicate that hypoadiponectinemia is associated with peripheral arterial dysfunction, hypertension, dyslipidemia and cancer initiation and poor prognosis [33,34]. Adiponectin inhibits ROS production as well as monocyte adhesion, which induces vasodilation. It also activates AMP kinase that leads to an increase in endothelial NO, synthase (eNOS) activity and NO production. The vascular system is protected by endothelial-derived NO, which enhances vasodilation and inhibits platelet aggregation, monocyte adhesion [35]. High glucose concentration induces production of ROS. However, adiponectin inhibits this process via cAMP/PKA-dependent pathway in endothelial cell [36].

Adiponectin attenuates the interaction between leukocytes and endothelial cells by suppressing the expression of E-selectin and vascular cell adhesion molecule-1. This adiponectin-related decrease in expression of adhesion molecules has been demonstrated in an animal model of atherosclerosis. Adiponectin inhibits the expression of adhesion molecules after induction by TNF- $\alpha$ and IL-8, which leads to reduction of monocyte attachment to endothelial cells [37]. Although adiponectin has numerous effects on the arterial wall, on the liver, as well as on insulin actions, its independent contribution to the etiology of CVD remains controversial as a systematic review and meta-analysis failed to identify it as an independent risk factor for cardiovascular outcomes [38]. Adiponectin plays a crucial mediator role in the pathogenesis of obesity-associated malignancies and its blood concentration reduces because of weight gain [34]. Clinical studies indicate that hypoadiponectinemia is associated with peripheral arterial dysfunction, hypertension, dyslipidemia and cancer initiation or progression [33,39]. Lower levels of adiponectin are also associated with poor colorectal and prostate cancer prognosis [34]. It is believed that adiponectin exerts its anticancer properties via direct and indirect mechanisms. It stimulates receptor-mediated signaling pathways and induces apoptosis. In an experimental study on HeLa cells by Xie et al. [40], it was observed that low adiponectin levels resulted in a significant increase in cell population in G0/G1 phase, concomitant with a reduction of cell number in S and G2/M phases which proves the inhibition of proliferation by adiponectin. In addition, they observed that adiponectin inhibited proliferation by downregulating cell cycle regulators such as cyclin D1 and c-myc and also activated apoptosis by inducing the expression of p21, p53 and Bax and the reduced 
level of Bcl-2 [41]. Recent studies by Mauro et al. also demonstrated that in breast cancer MDA-MB-231 xenograft models, the pre-treatment with adiponectin reduced tumor growth via amplifying AMP kinase signaling and reducing cyclin D1 expression [42,43]. Adiponectin may also act indirectly by modulating insulin sensitivity at the target tissue site, regulating inflammatory responses and influencing tumor angiogenesis. Adiponectin has a different isoform in different tissues and tumors, which may exert different effects on cancer initiation or suppression. Hence, the exact biological pathway linking adiponectin to cancer remains unclear and there are some controversial results [33].

Visfatin is another adipokine and cytosolic enzyme that was originally identified as pre-B cell colony-enhancing factor- 1 (PBEF) and has nicotinamide phosphoribosyl-transferase (Nampt) activity. Visfatin is predominantly produced in VAT. However, it is also produced by immune cells (e.g., neutrophils and macrophages) and induces expression of IL- $1 \mathrm{~b}$, TNF- $\alpha$, and especially IL-6 in human leukocytes [44]. Over the last decade, visfatin has been suggested as a potential link between obesity and both cardiovascular disease and cancer [45]. It also induces matrix metalloproteinase (MMP)-9 and NF-KB expression in human endothelial cells, as they play a critical role in the pathophysiology of vascular inflammation in obesity and atherosclerotic plaque instability [46].

In addition to the potential indirect role of visfatin in cardiovascular disease through metabolic syndrome and inflammation, visfatin has been demonstrated to induce endothelial dysfunction in vivo, which has a pivotal role in initiation and progress of atherosclerosis [47]. Romacho et al. have recently reported that visfatin induces endothelial dysfunction in mice by a Nampt-dependent Toll-like receptor-4-mediated pathway, involving nod-like-receptor-protein-3 (NLRP3)-inflammasome and paracrine IL-1 $\beta$ [48]. Wang et al. demonstrated that visfatin also stimulates vascular smooth muscle cells proliferation via nicotinamide mononucleotide-mediated ERK1/2 and p38 signaling [49]. Other direct actions on atherogenesis via induction of angiogenesis, increased levels and activity of matrix metalloproteinases (MMP 2 and 9) as well as the promotion of cell adhesion molecules like the intercellular adhesion molecule 1 (ICAM-1), vascular cell adhesion molecule 1 (VCAM-1) and E-selectin have also been proposed [47,50]. All these actions, especially in combination with other risk factors, might result in increased risk of atherosclerotic cardiovascular disease initiation and progression.

The emerging evidence regarding the abnormal expression of visfatin in many types of cancers and also significant correlation between high circulating visfatin levels and increased risk of cancer and cancer-related mortality, suggests visfatin as a potential mediator that contributes to the interconnection of obesity and cancer [51]. Visfatin regulates the proliferation of cancer cells, as demonstrated in melanoma cells, where visfatin/Nampt induces proliferation and inhibits p53-dependent apoptosis via the E2F2/SIRT1 axis [52]. Similar action has been reported from visfatin in other cancer cell lines through PI3K/Akt and MAPK/ERK1/2 signaling pathways [51,53]. In addition to induction of tumor cell proliferation, visfatin induces angiogenesis through activation of the mTOR pathway, thereby increasing the expression of vascular endothelial growth factor (VEGF) and HIF- $1 \alpha$ in endothelial cells [54]. Moreover, visfatin induces the expression of fibroblast growth factor (FGF)-2 gene in a Notch1-dependent manner, and triggers tube formation of endothelial cells [55].

\subsection{Insulin, Insulin Resistance and Insulin-Like Growth Factors (IGF)}

Visceral adiposity is also associated with metabolic dysfunction, increasing the risk of insulin resistance and hyperglycemia [9]. Several epidemiological studies indicate that insulin resistance and hyperinsulinemia are more important risk factors for some cancers and cardiovascular disease than obesity per se [56,57]. In terms of potential biological mechanisms, it has been suggested that the high concentrations of cytokines and low concentrations of adiponectin may interfere with glucose homoeostasis and lead to chronic hyperinsulinemia and insulin resistance [58]. Additionally, the rate of lipolysis is higher in VAT than subcutaneous adipose tissue, increasing the circulation of non-esterified fatty acids, which may affect hepatic insulin removal and lead to insulin resistance and hyperinsulinemia [59]. Insulin resistance decreases eNOS activation and NO production, which leads to the inflammation of plaque [58]. These steps sensitize plaque to rupture and consequently cause 
thrombotic vascular occlusion [60]. Several epidemiological studies have shown that insulin resistance is associated with an increased risk of breast, prostate and colon cancers [61].

Hyperinsulinemia may have carcinogenic effects via insulin receptors in the pre-neoplastic cells. It affects the insulin-like growth factors (IGF) axis, which leads to binding of IGF-1 or IGF-2 to the IGF-1 receptor promoting cell proliferation, differentiation and protection from apoptosis [62]. Epidemiological studies have shown that high endogenous or exogenous insulin release is associated with increased risk of colorectal, post-menopausal breast, pancreas and endometrium cancers [63].

IGF-1 level is significantly increased in individuals with obesity and this is a consequence of hyperinsulinemia inhibiting production of IGFBP-1 and -2 [64]. IGF-1 leads to macrophage migration and invasion and induces macrophage pro-inflammatory cytokines production. IGF-1 has pleotropic actions on heart and regulates contractility and heart apoptosis IGF-1 signaling. IGF-1 deficiency also increases the risk of cardiovascular disease, and IGF-1 receptor (IGF-1R) activation on heart protects it from effects of myocardial infarction [65]. Interestingly, high IGF-1 levels, common in patients with acromegaly, are associated with increased cardiovascular mortality too. Higher mortality from ischemic heart disease and stroke is seen in GH-deficient patients and/or low IGF-I levels, while high IGF-I levels induce cardiac hypertrophy and valve calcification [66]. IGF-1R activation promotes cell migration and affects E-cadherin and $\alpha$ - and $\beta$ - catenin (cell adhesion molecule). In different meta-analyses [63], increased levels of IGF-1 were associated with risk of ovarian [67], colorectal, prostate [68] pre- and post-menopausal breast cancers [69]. However, similarly to the association between IGF-1 and CVD, recent findings suggest that both low and high levels of IGF-1 are associated with cancer mortality [70]. Therefore, IGF-I levels have a U-shaped relation with CVD and cancer. In conclusion, both low and high IGF-1 appear to be risk factors for increased cancer and cardiovascular disease incidence and mortality.

\subsection{Sex Hormones and Lipid Profile}

Visceral fat mass is lower in female than males, but this difference is diminished in elderly people. Therefore, it seems that estrogen signaling plays a major role in sex differences in adiposity [71]. Clinical studies suggest that CVD risk is higher in males than in premenopausal females, regardless of body size. Plasma HDL cholesterol levels are significantly higher and fasting plasma glucose concentrations significantly lower in women compared to men who differ in VAT. This suggests that VAT is an important correlate of the gender differences observed in CVD risk [72]. In men, low circulating levels of total testosterone and sex hormone-binding globulin (SHBG), a determinant of testosterone bioavailability, are generally associated with abdominal and/or visceral obesity and affect metabolic syndrome [73].

Clinical studies have provided strong support regarding the association between sex hormones, obesity and cancer, specifically for hormone-dependent cancers such as endometrial, breast, uterine, ovarian, and prostate cancers [74] and for multiple myeloma and non-Hodgkin lymphoma [75]. Adipocytes influence sex hormone biology by increasing aromatase activity and consequently the production of estrogen in post-menopausal women, and of testosterone in men [76]. Estrogen is a well-known promoter of tumorigenesis through oncogenic transcriptional regulation of genes involved in cell survival and proliferation [77], and non-genomic crosstalk with growth factor pathways, including epidermal growth factor (EGF), IGF, and FGF [78]. Estrogen signaling disturbance plays a crucial role in the development of mammary tumors. Exogenous or parity-associated excessive estrogen supply is suppressive against triple negative but not ER-positive breast cancer, which reduces the ER expression of tumors and reduces the anticancer capacity. It seems that ER-positive or negative breast cancers have a different mechanism [79].

\subsection{Fibroblast Growth Factor}

FGFs comprise a broad family of polypeptides with significant biological roles. They are signaling proteins related to development and metabolism, covering 22 members in the mammalian FGF family. Secreted FGFs control important cellular processes that comprehend positive and negative regulation 
of proliferation, survival, migration, differentiation, and metabolism. FGFs may indirectly contribute to an inflammatory environment through the synergistic potentiation of inflammatory mediator-induced leukocyte recruitment, intensifying cell adhesion and molecule upregulation [80]. Some FGFs play a pathophysiological role in cardiovascular diseases [81] and in the development of various types of cancers [82].

In cardiovascular disease, some FGFs are implicated in cardiac remodeling through different mechanisms, which can contribute to heart failure [81]. For example, FGF2 induces cardiac hypertrophy through the activation of FGF receptor 1c and MAPK signaling, and FGF23 by activating calcineurin/NFAT signaling without $\alpha$ Klotho [81]. In tumor growth, the FGF receptor system plays important roles. The FGFR-1-mediated MAPK kinase pathway has been implicated in tumor cell proliferation. In skin carcinoma and oral carcinomas, FGFR-2 expression has been found to be associated with early tumor development.

Although FGFs are implicated in both cardiovascular disease and cancer development, different FGF family members are involved in the pathophysiology of these illnesses. In an experimental model with rats, fibroblast growth factor 2 (FGF2), secreted and released by the VAT, stimulated the transformation of skin epithelial cells, primarily in mice fed with a high-fat diet (60\% kcal from fat) [83]. This study also found that signaling through the tyrosine kinase FGF2 receptor-1 (FGFR1) plays an important role in FGF2-stimulated transformation, i.e., post-initiation phases a cell undergoes to become malignant [83]. Besides skin cancer, the FGF2-FGFR1 axis was also implicated in a VAT-stimulated transformation of breast epithelial cells [84]. Regarding cardiovascular diseases, we highlighted the role of FGF23. Although not secreted by the VAT, a recent study found FGF23 levels to be elevated among men and post-menopausal women with obesity, mainly those with abdominal obesity, suggesting an association with visceral fat accumulation [85]. Several studies have found an independent association of serum levels of FGF23 and heart disease [86-90].

\subsection{Alterations in DNA Methylation}

Changes in DNA methylation is one of the most studied epigenetic modifications at the molecular level [91]. DNA methylation consists of the addition of a methyl group in the position 5 of the DNA cytosine ring through DNA methyltransferases enzymes [92]. Long interspersed nuclear element 1 (LINE-1) has been implicated as a marker of the global DNA methylation of the genome [93]. The LINE-1 is usually heavily methylated and its hypomethylation has been associated with cancer development and progression [31]. Additionally, LINE-1 methylation variability has been linked with ischemic heart disease and stroke, suggesting they share a pathophysiological role between cancer and cardiovascular diseases.

DNA methylation in visceral adipose tissue has also been the subject of studies in recent years, given that it is an important mechanism that predisposes the development of obesity and metabolic impairment [94,95]. In a study of severely obese individuals, lower overall DNA methylation, assessed by analysis of LINE-1 in visceral adipose tissue, was associated with an increased risk of metabolic syndrome [96]. Hypomethylation of DNA may be a mechanism shared between metabolic changes in visceral adipose tissue and cancer.

\subsection{Other Biochemical and Metabolic Factors}

Mitochondrial dysfunction can promote various mechanisms during cancer progression. Mitochondrial alterations affect nuclear gene expression for neoplastic transformation. Alteration in the intracellular level of oncometabolites play a critical role in neoplastic transformation and cancer progression. In addition, other suppressors such as hypoxia-inducible factor 1 and p53, alter cellular metabolism [97]. Impairment of mitochondrial function in VAT was found to be linked to esophageal adenocarcinoma [98]. It has been shown in an in vitro study, that the adipose media of patients with obesity and esophageal adenocarcinoma induces mitochondrial dysfunction which in turn can promote carcinogenesis [98]. On the other hand, in an animal model, mice deficient in 
mitochondrial transcription factor A (TFAM) in adipocytes, one of the main regulators of mitochondrial mass and function, presented mitochondrial dysfunction that led to lipoatrophy, insulin resistance, hepatosteatosis, hypertension and cardiac dysfunction [99]. Additionally, lipodystrophy syndrome has been associated with insulin resistance and cardiovascular complications [99].

\section{Pharmacological Treatment of Visceral Obesity}

The development of pharmacological agents to reduce visceral obesity is difficult due to various potential side effects [100]. For example, regulatory authorities in visceral obesity and weight loss had approved dexfenfluramine, sibutramine, and rimonabant. However, they were removed from clinical use because of their various side effects. In this section, we introduce the clinical and experimental drugs that can probably reduce visceral fat that affects the risk of cancer and CVD. The summary of the effects from pharm therapy on cancer and CVD is presented in Table 2.

Table 2. Drugs for joint pharmacologic prevention of visceral obesity, cardiovascular disease and cancer.

\begin{tabular}{|c|c|c|c|c|}
\hline Drugs & Direct Target & $\begin{array}{c}\text { Action on Visceral } \\
\text { Obesity }\end{array}$ & Action on Cancer & Action on CVD \\
\hline PPAR $\gamma$ agonists & $\begin{array}{l}\text { Peroxisome } \\
\text { proliferator-activated } \\
\text { receptor Gamma }\end{array}$ & Adipokine /IGF & $\begin{array}{l}\text { Reduce circulating } \\
\text { insulin, } \\
\text { Reduce Angiogenesis } \\
\text { Increase Apoptosis }\end{array}$ & $\begin{array}{c}\text { Reduce blood pressure } \\
\text { Reduce myocardial } \\
\text { infarction and stroke } \\
\text { Improve endothelial } \\
\text { function }\end{array}$ \\
\hline $\begin{array}{l}\text { Recombinant } \\
\text { human growth } \\
\text { hormones }\end{array}$ & Growth hormone & Increase lipolysis/IGF-I & $\begin{array}{l}\text { Reduce risk of cancer } \\
\text { in adults with growth } \\
\text { hormone deficiency }\end{array}$ & $\begin{array}{l}\text { Reduce risk of MI in } \\
\text { adults with growth } \\
\text { hormone deficiency }\end{array}$ \\
\hline Metformin & Unknown & $\begin{array}{c}\text { Induces anorexia, } \\
\text { upregulates adaptive } \\
\text { thermogenes, and } \\
\text { modulates adipokines } \\
\text { Improves } \\
\text { mithocondrial } \\
\text { dysfunction }\end{array}$ & $\begin{array}{l}\text { Reduces pre-neoplastic } \\
\text { and neoplastic cell } \\
\text { proliferation } \\
\text { Reduces circulating } \\
\text { levels of androgen and } \\
\text { estrogen }\end{array}$ & $\begin{array}{c}\text { Increases eNOS } \\
\text { production } \\
\text { Attenuates ER } \\
\text { stress-induced } \\
\text { mitochondrial } \\
\text { dysfunction } \\
\text { Reduces cardiac injury } \\
\text { through ER-stress }\end{array}$ \\
\hline NSAIDs & Cycloxyganase & $\begin{array}{l}\text { Reduce prostaglandin } \\
\text { levels } \\
\text { Modulate adiponectin }\end{array}$ & Reduce inflammation & $\begin{array}{l}\text { Reduce platelet } \\
\text { aggregation and } \\
\text { vasoconstriction }\end{array}$ \\
\hline Statins & HMG-CoA reductase & $\begin{array}{l}\text { Increase circulating } \\
\text { adiponectin }\end{array}$ & $\begin{array}{l}\text { Tumor-suppressor } \\
\text { Increase Apoptosis }\end{array}$ & $\begin{array}{l}\text { Improve endothelial } \\
\text { function } \\
\text { Plaque stabilization }\end{array}$ \\
\hline Ezetimibe & $\begin{array}{l}\text { Niemann-Pick } \\
\text { C1-like } 1 \text { blocker }\end{array}$ & $\begin{array}{l}\text { Modulate adiponectin } \\
\text { Decrease insulin } \\
\text { resistant which results }\end{array}$ & $\begin{array}{l}\text { Suppress inflammation } \\
\text { Inhibiting angiogenesis }\end{array}$ & $\begin{array}{c}\text { Reduces in blood level } \\
\text { of TNF- } \alpha \text { in patients } \\
\text { with hyperlipidemia }\end{array}$ \\
\hline
\end{tabular}

\subsection{Peroxisome Proliferator-Activated Receptor Gamma (PPAR $\gamma$ )}

This ligand-activated transcription factor has critical roles in various cellular functions and glucose and lipid metabolism [101]. PPAR $\gamma$ is found in abundance in the adipose tissue where this receptor acts as a lipid sensor. The activation of PPAR $\gamma$ (by its ligands) leads to adipokine secretion [102] which reduces visceral fat, but not necessarily body weight. It has been suggested that pioglitazone (PPAR $\gamma$ agonists) decreases visceral fat, however, it may increase total body weight [103]. PPAR $\gamma$ agonists have cardiovascular protective effects, but some adverse cardiovascular events such as congestive heart failure and myocardial infarction have been detected with these drugs. For example, pioglitazone showed a reduction in the risk of MI (miocard infarction), stroke or death in patients with type 2 diabetes mellitus [104] in a recent meta-analysis. However, another meta-analysis showed that rosiglitazone increased the risk of MI but with low mortality risk [105].

PPAR- $\gamma$ agonists decrease tumor proliferation by lowering circulating insulin and affecting key pathways of the Insulin/IGF axis, such as PI3K/mTOR, MAPK, and GSK3- $\beta / \mathrm{Wnt} / \beta$-catenin cascades, 
which regulate cancer cell survival, cell reprogramming, and differentiation [106]. One meta-analysis supported a protective association between PPAR- $\gamma$ agonists' use and reduction of colon cancer risk in patients with DM [107]. On the other hand, in human studies, it has been shown that Pioglitazone can increase the risk of bladder cancer in humans [108] depending on its dosage. While Pioglitazone decreases the risk of breast cancer. The other PPAR agonist, rosiglitazone, decreased [109] the risk of bowel cancer significantly. Therefore, the effect on cancer may be site and drug specific.

\subsection{Growth Hormone Treatment}

Growth hormone (GH) treatment is not effective in treating visceral obesity in patients with normal levels but its deficiency leads to obesity or visceral obesity [110]. It has been suggested that GH therapy decreases visceral adiposity and improves lipid profile in adults with obesity [111]. This effect results from GH lipolysis properties [112]. However, IGF-I and IGFBP-3 levels are more related to visceral adipose tissue accumulation than overall adiposity [113].

Recombinant human growth hormone (rhGH) has been widely used to treat children with short stature secondary to any medical problems. The experience from many thousands of patients and years of treatment demonstrates a good safety record for rhGH. Nevertheless, the findings from a meta-analysis showed a significant increase in all-cause mortality but no significant increase in the malignancy and CVD mortality. The risk for second neoplasms increases in these patients [114].

A recent meta-analysis evaluated the risk of cancer in adults with and without growth hormone replacement therapy, which suggested that growth hormone replacement therapy could reduce the risk of cancer in adults with growth hormone deficiency [115].

\subsection{Metformin}

Metformin, a biguanide anti-hyperglycemic agent, is the first line treatment for overweight diabetes patients [116]. It reduces liver glucose production, increases cells insulin sensitivity and induces anorexia effect [117]. Metformin treatment up-regulates adipose oxidation-related enzymes in the liver and also UCP-1 in the brown adipose tissue which leads to reductions in abdominal obesity in mice [118]. In addition, metformin can reduce visceral adiposity by upregulating adaptive thermogenesis [119].

Metformin has protective effects on cardiovascular problems in patients with type 2 diabetes which are independent from the glucose-lowering effect [120]. Metformin activates AMPK promoting glycolysis. Metformin also increases eNOS production, which results in beneficial effects in patients with heart failure [121]. Metformin attenuated ER stress-induced mitochondrial dysfunction in myocardial cells, which results in reduction of cardiac injury through ER-stress [122].

Metformin increases glucose uptake and insulin sensitivity and reduces serum insulin level which results in reduction of pre-neoplastic and neoplastic cell proliferation [123]. Metformin also reduces circulating levels of androgen and estrogen, which is another potential mechanism of metformin in the prevention of cancer incidence [124]. Metformin inhibits mTOR activity and activates p53 which reduces the cell cycle. Metformin reduces mortality risk and recurrence of cancers in clinical studies and also sensitizes cancer cells to chemo and radiotherapy [123]. The most recent meta-analysis confirms the association between metformin use and reduction of pancreatic and colorectal cancer incidence $[63,125]$.

\subsection{Cycloxyganase Inhibitors}

Elevated levels of cyclooxygenase (COX), a sign of chronic inflammation, is the key connection between cancer and obesity. Non-steroidal anti-inflammatory drugs (NSAIDs) reduce inflammation via COX inhibition which ultimately reduces prostaglandin levels [126]. They also have a different effect on visceral obesity and adipose reduction [127].

The results from randomized controlled trials (RCTs) and meta-analyses show that there is a significant increase in risk of heart attack in patients who are taking COX inhibitors compared with 
placebo [128]. The possible mechanisms are due to the fact that prostacyclin reductions lead to platelet aggregation and vasoconstriction [129]. Cancer cells and tissues upregulate the expression of COX which is inversely associated with cancer incidence and recurrence [130]. It has been confirmed that COX inhibitors can reduce the risk of breast cancer in women [131]. However, because of adverse cardiovascular effects, they are not currently prescribed for prevention of cancer risk and recurrence.

Aspirin, an irreversible inhibitor of the COX enzyme [132], is an exception, which has protective effects on the cardiovascular system. It has been confirmed that low-dose aspirin use may reduce the risk of cancer. These observations coincide with recent in vivo and clinical studies showing a functional relationship between platelets and tumors, suggesting that aspirin's chemo preventive properties may result, in part, from direct modulation of platelet biology and biochemistry [133].

\subsection{Statins}

Statins, HMG-CoA reductase inhibitors, are the most common lipid-lowering medications and are widely prescribed. They are effective in lowering cholesterol and play a critical role in the prevention of primary and secondary cardiovascular disease [134]. Statins also decrease chronic inflammation and oxidative stress, which is another possible mechanism in preventing cardiovascular disease [135]. It seems that some types of statins, such as pitavastatin may increase circulating adiponectin. However, data are conflicting [136]. A recent study confirmed that atorvastatin and rosuvastatin (two other statins) reduce epicardial adipose tissue in post-menopausal women independent of their lipid-lowering property [137]. However, it seems that different types of statins may have different effects.

There are several meta-analyses on the effect of statins and cancer incidence and also relapse with some showing beneficial effects while others found no effects. A risk reduction has been observed in esophageal [138], colorectal [139] and gastric cancer [140]. It seems that they may reduce the risk of mortality from cancer too [141,142].

\subsection{Ezetimibe}

Ezetimibe is another lipid-lowering drug which limits the absorption of cholesterol from the gastrointestinal tract epithelial. It blocks the Niemann-Pick C1-like 1 (NPC1L1) protein on small intestine epithelial cells, which leads to reduction of plasma level of cholesterol [143].

There is some evidence suggesting that ezetimibe has an effect on adiponectin and decreases insulin resistance which results in adipose tissue reduction in patients with metabolic syndrome [144]. Adding ezetimibe to statin therapy is associated with a greater reduction in blood level of TNF- $\alpha$ in patients with hyperlipidemia [145].

Ezetimibe in combination with statin, has beneficial effects on the risk reduction of non-fatal MI. However, there is limited evidence about its monotherapy and CVD risk reduction [146]. It has been shown that ezetimibe could suppress inflammation and liver tumor growth in animal models of a high fat diet. It seems that inhibiting angiogenesis in mice leads to tumor suppression [147]. However, cholesterol lowering by ezetimibe did not slow prostate tumor growth and may induce expression of LDL receptor in cancer cells [148].

\section{Conclusions}

In this review, we discussed some pathophysiological aspects shared between VAT, cardiovascular disease and cancer as well as their shared pharmacological prevention. Chronic inflammation and dysregulated metabolism associated to visceral obesity, such as insulin resistance, hyperglycemia, and dyslipidemia can affect both CVD and cancer development and progression. The shared disease pathways linking visceral obesity to cancer and CVD may offer valuable opportunities for public health interventions to tackle both diseases. Reductions in abdominal and visceral adiposity improve insulin sensitivity, lipid profile and cytokines, which consequently reduce the risk of CVD and some cancer types. In fact, in addition to lifestyle interventions, pharmacotherapy with antidiabetic drugs, $\operatorname{PPAR} \gamma$ and recombinant growth hormone may decrease the risk of both visceral obesity and cancer. 
Several medications have been shown to reduce visceral and/or subcutaneous fat. However, none of them have been approved for use in this context. Further research on the shared pathophysiological mechanisms underlying the association between visceral obesity, CVD and cancer could potentially lead to the discovery of important biomarkers and pathways and development and assessment of effective therapies. New pharmacological treatments that selectively affect the shared pathways, are needed. Long term, well designed RCTs and cohort studies should be conducted to test the hypothesis of targeting shared mechanisms aiming to prevent VAT, cancer and CVD. The role of visceral fat in cancer and CVD is an important area to advance in public health policies. It is also important to increase public awareness about its role and ways to manage or prevent it.

Author Contributions: E.A.S. was responsible for writing the draft of the manuscript and performing major revisions of the manuscript, G.V. and A.S.d.C.S. developed the figure and wrote some parts. A.S.d.C.S., F.M., M.N., N.M., C.d.O., edited the whole manuscript and wrote some parts. N.K. wrote some parts and critically revised the manuscript. N.S. and E.A.S. developed the idea, wrote some parts, edited the whole manuscript and supervised the whole project. C.d.O. edited the whole manuscript and critically revised. All authors have read and agreed to the published version of the manuscript.

Funding: Cesar de Oliveira is supported by the Economic and Social Research Council (ESRC) (Grant ES/T008822/11).

Acknowledgments: The authors acknowledged the Universidade Federal se Goias (UFG) and the Instituto Federal Goiano as well as Isfahan Cardiovascular Research Institute for the Technical assistance and support. Cesar de Oliveira is supported by the Economic and Social Research Council (grant ES/T008822/1).

Conflicts of Interest: All authors report no conflict of interest.

Disclaimer: Where authors are identified as personnel or advisors of the International Agency for Research on Cancer or the World Health Organization, the authors alone are responsible for the views expressed in this article and they do not necessarily represent the decisions, policy or views of their affiliated agencies.

\section{References}

1. Tchernof, A.; Després, J.-P. Pathophysiology of Human Visceral Obesity: An Update. Physiol. Rev. 2013, 93, 359-404. [CrossRef]

2. Riaz, H.; Khan, M.S.; Siddiqi, T.J.; Usman, M.S.; Shah, N.; Goyal, A.; Khan, S.; Mookadam, F.; Krasushi, R.A.; Ahmed, H. Association Between Obesity and Cardiovascular Outcomes. JAMA Netw. Open 2018, 1, e183788. [CrossRef] [PubMed]

3. Barberio, A.M.; Alareeki, A.; Viner, B.; Pader, J.; Vena, J.E.; Arora, P.; Friedenreich, C.M.; Brenner, D.R. Central body fatness is a stronger predictor of cancer risk than overall body size. Nat. Commun. 2019, 10, 383. [CrossRef] [PubMed]

4. Silveira, E.A.; Ferreira, C.C.D.C.; Pagotto, V.; Santos, A.S.E.A.D.C.; Velasquez-Melendez, G. Total and central obesity in elderly associated with a marker of undernutrition in early life-Sitting height-to-stature ratio: A nutritional paradox. Am. J. Hum. Biol. 2017, 29, e22977. [CrossRef] [PubMed]

5. Silveira, E.A.; Kliemann, N.; Noll, M.; Sarrafzadegan, N.; Oliveira, C. Visceral obesity and incident cancer and cardiovascular disease: An integrative review of the epidemiological evidence. Obes. Rev. 2020, 1, obr.13088. [CrossRef] [PubMed]

6. Fund, W.C.R. Body Fatness and Weight Gain and the Risk of Cancer. American Institute for Cancer Research, 2018. Available online: https://www.wcrf.org/sites/default/files/Body-fatness-and-weight-gain_0. pdf (accessed on 24 November 2020).

7. Doyle, S.L.; Donohoe, C.L.; Lysaght, J.; Reynolds, J.V. Visceral obesity, metabolic syndrome, insulin resistance and cancer. Proc. Nutr. Soc. 2012, 71, 181-189. [CrossRef] [PubMed]

8. Williams, S.C.P. Link between obesity and cancer. Proc. Natl. Acad. Sci. USA 2013, 110, 8753-8754. [CrossRef]

9. Deng, T.; Lyon, C.J.; Bergin, S.; Caligiuri, M.A.; Hsueh, W.A. Obesity, Inflammation, and Cancer. Annu. Rev. Pathol. Mech. Dis. 2016, 11, 421-449. [CrossRef]

10. Lumeng, C.N.; Bodzin, J.L.; Saltiel, A.R. Obesity induces a phenotypic switch in adipose tissue macrophage polarization. J. Clin. Investig. 2007, 117, 175-184. [CrossRef] 
11. Lopez-Candales, A.; Hernández Burgos, P.M.; Hernandez-Suarez, D.F.; Harris, D. Linking Chronic Inflammation with Cardiovascular Disease: From Normal Aging to the Metabolic Syndrome. J. Nat. Sci. 2017, 3, e341.

12. Coussens, L.M.; Werb, Z. Inflammation and cancer. Nature 2002, 420, 860-867. [CrossRef] [PubMed]

13. Fernandes, J.V.; Cobucci, R.N.O.; Jatobá, C.A.N.; de Medeiros Fernandes, T.A.A.; de Azevedo, J.W.V.; de Araújo, J.M.G. The Role of the Mediators of Inflammation in Cancer Development. Pathol. Oncol. Res. 2015, 21, 527-534. [CrossRef]

14. Masoudkabir, F.; Sarrafzadegan, N.; Gotay, C.; Ignaszewski, A.; Krahn, A.D.; Davis, M.K.; Franco, C.; Mani, A. Cardiovascular disease and cancer: Evidence for shared disease pathways and pharmacologic prevention. Atherosclerosis 2017, 263, 343-351. [CrossRef] [PubMed]

15. Multhoff, G.; Molls, M.; Radons, J. Chronic Inflammation in Cancer Development. Front. Immunol. $2012,2$. [CrossRef]

16. Lu, H. Inflammation, a Key Event in Cancer Development. Mol. Cancer Res. 2006, 4, 221-233. [CrossRef]

17. Munn, L.L. Cancer and inflammation. Wiley Interdiscip. Rev. Syst. Biol. Med. 2017, 9, e1370. [CrossRef] [PubMed]

18. Schmitz, J.; Evers, N.; Awazawa, M.; Nicholls, H.T.; Bronneke, H.S.; Dietrich, A.; Mauer, J.; Bluher, M.; Bruning, J.C. Obesogenic memory can confer long-term increases in adipose tissue but not liver inflammation and insulin resistance after weight loss. Mol. Metab. 2016, 5, 328-339. [CrossRef]

19. Longo, M.; Zatterale, F.; Naderi, J.; Parrillo, L.; Formisano, P.; Raciti, G.A.; Beguinot, F.; Miele, C. Adipose Tissue Dysfunction as Determinant of Obesity-Associated Metabolic Complications. Int. J. Mol. Sci. 2019, 20, 2358. [CrossRef]

20. Cancello, R.; Henegar, C.; Viguerie, N.; Taleb, S.; Poitou, C.; Rouault, C.; Coupaye, M.; Pelloux, V.; Hugol, D.; Bouillot, J.-L.; et al. Reduction of Macrophage Infiltration and Chemoattractant Gene Expression Changes in White Adipose Tissue of Morbidly Obese Subjects After Surgery-Induced Weight Loss. Diabetes 2005, 54, 2277-2286. [CrossRef]

21. Chen, B.; Lam, K.S.L.; Wang, Y.; Wu, D.; Lam, M.C.; Shen, J.; Wong, L.; Hoo, R.L.; Zhang, J.; Xu, A. Hypoxia dysregulates the production of adiponectin and plasminogen activator inhibitor-1 independent of reactive oxygen species in adipocytes. Biochem. Biophys. Res. Commun. 2006, 341, 549-556. [CrossRef]

22. Wueest, S.; Rapold, R.A.; Rytka, J.M.; Schoenle, E.J.; Konrad, D. Basal lipolysis, not the degree of insulin resistance, differentiates large from small isolated adipocytes in high-fat fed mice. Diabetologia 2009, 52, 541-546. [CrossRef]

23. Castoldi, A.; Naffah de Souza, C.; Câmara, N.O.S.; Moraes-Vieira, P.M. The Macrophage Switch in Obesity Development. Front. Immunol. 2016, 6. [CrossRef] [PubMed]

24. Loffek, S.; Schilling, O.; Franzke, C.-W. Biological role of matrix metalloproteinases: A critical balance. Eur. Respir. J. 2011, 38, 191-208. [CrossRef] [PubMed]

25. Walter, L. Role of Matrix Metalloproteinases in Inflammation/Colitis-Associated Colon Cancer. Immunogastroenterology 2013, 2, 22. [CrossRef]

26. Wu, L.-J.; Li, H.-X.; Luo, X.-T.; Lu, R.-Z.; Ma, Y.-F.; Wang, R.; Zhang, J.; Yang, D.-Q.; Yu, H.; Liu, J. STAT3 activation in tumor cell-free lymph nodes predicts a poor prognosis for gastric cancer. Int. J. Clin. Exp. Pathol. 2014, 7, 1140-1146. [PubMed]

27. Porporato, P.E.; Filigheddu, N.; Bravo-San Pedro, J.M.; Kroemer, G.; Galluzzi, L. Mitochondrial metabolism and cancer. Cell. Res. 2018, 28, 265-280. [CrossRef] [PubMed]

28. Sung, H.J.; Ma, W.; Starost, M.F.; Lago, C.U.; Lim, P.K.; Sack, M.N.; Kang, J.-G.; Wang, P.-Y.; Hwang, P.M. Ambient Oxygen Promotes Tumorigenesis. PLoS ONE 2011, 6, e19785. [CrossRef]

29. Liou, G.-Y.; Döppler, H.; DelGiorno, K.E.; Zhang, L.; Leitges, M.; Crawford, H.C.; Murphy, M.P.; Storz, P. Mutant KRas-Induced Mitochondrial Oxidative Stress in Acinar Cells Upregulates EGFR Signaling to Drive Formation of Pancreatic Precancerous Lesions. Cell. Rep. 2016, 14, 2325-2336. [CrossRef]

30. Fu, Y.; Luo, N.; Klein, R.L.; Garvey, W.T. Adiponectin promotes adipocyte differentiation, insulin sensitivity, and lipid accumulation. J. Lipid Res. 2005, 46, 1369-1379. [CrossRef]

31. Zhu, W.; Cheng, K.K.Y.; Vanhoutte, P.M.; Lam, K.S.L.; Xu, A. Vascular effects of adiponectin: Molecular mechanisms and potential therapeutic intervention. Clin. Sci. 2008, 114, 361-374. [CrossRef]

32. Parida, S.; Siddharth, S.; Sharma, D. Adiponectin, Obesity, and Cancer: Clash of the Bigwigs in Health and Disease. Int. J. Mol. Sci. 2019, 20, 2519. [CrossRef] [PubMed] 
33. Muppala, S.; Konduru, S.K.; Merchant, N.; Ramsoondar, J.; Rampersad, C.K.; Rajitha, B.; Mukund, V.; Kancherla, J.; Hammond, A.; Barik, T.K.; et al. Adiponectin, Its role in obesity-associated colon and prostate cancers. Crit. Rev. Oncol. Hematol. 2017, 116, 125-133. [CrossRef] [PubMed]

34. Dalamaga, M.; Diakopoulos, K.N.; Mantzoros, C.S. The Role of Adiponectin in Cancer: A Review of Current Evidence. Endocr. Rev. 2012, 33, 547-594. [CrossRef] [PubMed]

35. Diez, J.; Iglesias, P. The role of the novel adipocyte-derived hormone adiponectin in human disease. Eur. J. Endocrinol. 2003, 148, 293-300. [CrossRef]

36. Nedvídková, J.; Smitka, K.; Kopský, V.H.V. Adiponectin, an adipocyte-derived protein. Physiol. Res. 2005, 54, 133-140.

37. Mohammadi, S.; Arefhosseini, S.R.; Ebrahimi-Mamaeghani, M.; Fallah, P.; Bazi, Z. Adiponectin as a potential biomarker of vascular disease. Vasc. Health Risk Manag. 2015, 11, 55. [CrossRef]

38. Kanhai, D.A.; Kranendonk, M.E.; Uiterwaal, C.S.P.M.; van der Graaf, Y.; Kappelle, L.J.; Visseren, F.L.J. Adiponectin and incident coronary heart disease and stroke. A systematic review and meta-analysis of prospective studies. Obes. Rev. 2013, 14, 555-567. [CrossRef]

39. Ouchi, N.; Ohishi, M.; Kihara, S.; Funahashi, T.; Nakamura, T.; Nagaretani, H.; Kumada, M.; Ohashi, K.; Okamoto, Y.; Nishizawa, H.; et al. Association of Hypoadiponectinemia With Impaired Vasoreactivity. Hypertension 2003, 42, 231-234. [CrossRef]

40. Xie, L.; Wang, Y.; Wang, S.; Wu, N.; Chen, Y.; Yan, J. Adiponectin induces growth inhibition and apoptosis in cervical cancer HeLa cells. Biologia (Bratisl) 2011, 66. [CrossRef]

41. Gelsomino, L.; Naimo, G.D.; Catalano, S.; Mauro, L.; Andò, S. The Emerging Role of Adiponectin in Female Malignancies. Int. J. Mol. Sci. 2019, 20, 2127. [CrossRef]

42. Mauro, L.; Naimo, G.D.; Gelsomino, L.; Malivindi, R.; Bruno, L.; Pellegrino, M.; Tarallo, R.; Memoli, D.; Weisz, A.; Panno, M.S.; et al. Uncoupling effects of estrogen receptor $\alpha$ on LKB1/AMPK interaction upon adiponectin exposure in breast cancer. FASEB J. 2018, 32, 4343-4355. [CrossRef] [PubMed]

43. Mauro, L.; Pellegrino, M.; Giordano, F.; Ricchio, E.; Rizza, P.; De Amicis, F.; Catalano, S.; Bonofiglio, D.; Panno, M.L.; Andò, S. Estrogen receptor- $\alpha$ drives adiponectin effects on cyclin D1 expression in breast cancer cells. FASEB J. 2015, 29, 2150-2160. [CrossRef] [PubMed]

44. Karbaschian, Z.; Hosseinzadeh-Attar, M.J.; Giahi, L.; Golpaie, A.; Masoudkabir, F.; Talebpour, M.; Kosari, F.; Karbaschian, N.; Hoseini, M.; Mazaherioun, M. Portal and systemic levels of visfatin in morbidly obese subjects undergoing bariatric surgery. Endocrine 2013, 44, 114-118. [CrossRef] [PubMed]

45. Ashraf, H.; Soltani, D.; Sobh-Rakhshankhah, A.; Jafari, S.; Boroumand, M.A.; Goudarzi, V.; VasheghaniFarahani, A.; Masoudkabir, F. Visfatin as marker of isolated coronary artery ectasia and its severity. Cytokine 2019, 113, 216-220. [CrossRef] [PubMed]

46. Landecho, M.F.; Tuero, C.; Valentí, V.; Bilbao, I.; de la Higuera, M.; Frühbeck, G. Relevance of Leptin and Other Adipokines in Obesity-Associated Cardiovascular Risk. Nutrients 2019, 11, 2664. [CrossRef]

47. Romacho, T.; Sánchez-Ferrer, C.F.; Peiró, C. Visfatin/Nampt: An Adipokine with Cardiovascular Impact. Mediators Inflamm. 2013, 2013, 1-15. [CrossRef]

48. Romacho, T.; Valencia, I.; Ramos-González, M.; Vallejo, S.; López-Esteban, M.; Lorenzo, O.; Cannata, P.; Romero, A.; San Hipólito-Luengo, A.; Gómez-Cerezo, J.F.; et al. Visfatin/eNampt induces endothelial dysfunction in vivo: A role for Toll-Like Receptor 4 and NLRP3 inflammasome. Sci. Rep. 2020, 10, 5386. [CrossRef]

49. Wang, P.; Xu, T.-Y.; Guan, Y.-F.; Su, D.-F.; Fan, G.-R.; Miao, C.-Y. Perivascular adipose tissue-derived visfatin is a vascular smooth muscle cell growth factor: Role of nicotinamide mononucleotide. Cardiovasc. Res. 2009, 81, 370-380. [CrossRef]

50. Kim, S.-R.; Bae, Y.-H.; Bae, S.-K.; Choi, K.-S.; Yoon, K.-H.; Koo, T.H.; Jang, H.-O.; Yun, I.; Kim, K.-W.; Kwon, Y.-G.; et al. Visfatin enhances ICAM-1 and VCAM-1 expression through ROS-dependent NF-kB activation in endothelial cells. Biochim. Biophys. Acta Mol. Cell. Res. 2008, 1783, 886-895. [CrossRef]

51. Lin, T.-C. The role of visfatin in cancer proliferation, angiogenesis, metastasis, drug resistance and clinical prognosis. Cancer Manag. Res. 2019, 11, 3481-3491. [CrossRef]

52. Zhao, H.; Tang, W.; Chen, X.; Wang, S.; Wang, X.; Xu, H.; Li, L. The NAMPT/E2F2/SIRT1 axis promotes proliferation and inhibits p53-dependent apoptosis in human melanoma cells. Biochem. Biophys. Res. Commun. 2017, 493, 77-84. [CrossRef] [PubMed] 
53. Wang, Y.; Gao, C.; Zhang, Y.; Gao, Y.; Teng, F.; Tian, W.; Yang, W.; Yan, Y.; Xue, F. Visfatin stimulates endometrial cancer cell proliferation via activation of PI3K/Akt and MAPK/ERK1/2 signalling pathways. Gynecol. Oncol. 2016, 143, 168-178. [CrossRef] [PubMed]

54. Park, J.-W.; Kim, W.-H.; Shin, S.-H.; Kim, J.Y.; Yun, M.R.; Park, K.J.; Park, H.-Y. Visfatin exerts angiogenic effects on human umbilical vein endothelial cells through the mTOR signaling pathway. Biochim. Biophys. Acta Mol. Cell. Res. 2011, 1813, 763-771. [CrossRef] [PubMed]

55. Bae, Y.-H.; Park, H.-J.; Kim, S.-R.; Kim, J.-Y.; Kang, Y.; Kim, J.-A.; Wee, H.-J.; Kageyama, R.; Jung, J.S.; Bae, M.-K.; et al. Notch1 mediates visfatin-induced FGF-2 up-regulation and endothelial angiogenesis. Cardiovasc. Res. 2011, 89, 436-445. [CrossRef]

56. Kabat, G.C.; Kim, M.Y.; Lee, J.S.; Ho, G.Y.; Going, S.B.; Beebe-Dimmer, J.; Manson, J.E.; Chlebowski, R.T.; Rohan, T. Metabolic Obesity Phenotypes and Risk of Breast Cancer in Postmenopausal Women. Cancer Epidemiol. Biomarkers Prev. 2017, 26, 1730-1735. [CrossRef]

57. Liang, X.; Margolis, K.L.; Hendryx, M.; Rohan, T.E.; Groessl, E.J.; Thomson, C.A.; Kroenke, C.H.; Simon, M.S.; Lane, D.; Stefanick, M.; et al. Metabolic Phenotype and Risk of Colorectal Cancer in Normal-Weight Postmenopausal Women. Cancer Epidemiol. Biomark. Prev. 2017, 26, 155-161. [CrossRef]

58. Greenberg, A.S.; McDaniel, M.L. Identifying the links between obesity, insulin resistance and beta-cell function: Potential role of adipocyte-derived cytokines in the pathogenesis of type 2 diabetes. Eur. J. Clin. Investig. 2002, 32, 24-34. [CrossRef]

59. Frayn, K.N. Visceral fat and insulin resistance-Causative or correlative? Br. J. Nutr. 2000, 83, S71-S77. [CrossRef]

60. Paneni, F.; Costantino, S.; Cosentino, F. Insulin Resistance, Diabetes, and Cardiovascular Risk. Curr. Atheroscler. Rep. 2014, 16, 419. [CrossRef]

61. Donohoe, C.L.; Doyle, S.L.; Reynolds, J.V. Visceral adiposity, insulin resistance and cancer risk. Diabetol. Metab. Syndr. 2011, 3, 12. [CrossRef]

62. Gallagher, E.J.; LeRoith, D. Minireview: IGF, Insulin, and Cancer. Endocrinology 2011, 152, $2546-2551$. [CrossRef] [PubMed]

63. Mansourian, M.; Karimi, R.; Vaseghi, G. Different effects of metformin and insulin on primary and secondary chemoprevention of colorectal adenoma in diabetes type 2: Traditional and Bayesian meta-analysis. EXCLI J. 2018, 17, 45-56. [PubMed]

64. Lukanova, A.; Söderberg, S.; Stattin, P.; Palmqvist, R.; Lundin, E.; Biessy, C.; Rinaldi, S.; Riboli, E.; Hallmans, G.; Kaaks, R. Nonlinear relationship of insulin-like growth factor (IGF)-I and IGF-I/IGF-binding protein-3 ratio with indices of adiposity and plasma insulin concentrations (Sweden). Cancer Causes Control 2002, 13, 509-516. [CrossRef] [PubMed]

65. Troncoso, R.; Ibarra, C.; Vicencio, J.M.; Jaimovich, E.; Lavandero, S. New insights into IGF-1 signaling in the heart. Trends Endocrinol. Metab. 2014, 25, 128-137. [CrossRef] [PubMed]

66. Burgers, A.M.G.; Biermasz, N.R.; Schoones, J.W.; Pereira, A.M.; Renehan, A.G.; Zwahlen, M.; Egger, M.; Dekkers, O.M. Meta-analysis and dose-response metaregression: Circulating insulin-like growth factor I (IGF-I) and mortality. J. Clin. Endocrinol. Metab. 2011, 96, 2912-2920. [CrossRef] [PubMed]

67. Li, Y.; Li, Y.; Zhang, J.; Zheng, C.; Zhu, H.; Yu, H.; Fan, L. Circulating Insulin-Like Growth Factor-1 Level and Ovarian Cancer Risk. Cell. Physiol. Biochem. 2016, 38, 589-597. [CrossRef]

68. Morris, P.G.; Hudis, C.A.; Giri, D.; Morrow, M.; Falcone, D.J.; Zhou, X.K.; Du, B.; Brogi, E.; Crawford, C.B.; Kopelovich, L.; et al. Inflammation and Increased Aromatase Expression Occur in the Breast Tissue of Obese Women with Breast Cancer. Cancer Prev. Res. 2011, 4, 1021-1029. [CrossRef]

69. Shi, R.; Yu, H.; McLarty, J.; Glass, J. IGF-I and breast cancer: A meta-analysis. Int. J. Cancer 2004, 111, 418-423. [CrossRef]

70. Svensson, J.; Carlzon, D.; Petzold, M.; Karlsson, M.K.; Ljunggren, Ö.; Tivesten, Å.; Mellström, D.; Ohlsson, C. Both Low and High Serum IGF-I Levels Associate with Cancer Mortality in Older Men. J. Clin. Endocrinol. Metab. 2012, 97, 4623-4630. [CrossRef]

71. Camhi, S.M.; Bray, G.A.; Bouchard, C.; Greenway, F.L.; Johnson, W.D.; Newton, R.L.; Ravussin, E.; Ryan, D.H.; Smith, S.R.; Katzmarzyk, P.T. The Relationship of Waist Circumference and BMI to Visceral, Subcutaneous, and Total Body Fat: Sex and Race Differences. Obesity 2011, 19, 402-408. [CrossRef] 
72. Mongraw-Chaffin, M.L.; Anderson, C.A.M.; Allison, M.A.; Ouyang, P.; Szklo, M.; Vaidya, D.; Woodward, M.; Golden, S.H. Association Between Sex Hormones and Adiposity: Qualitative Differences in Women and Men in the Multi-Ethnic Study of Atherosclerosis. J. Clin. Endocrinol. Metab. 2015, 100, E596-E600. [CrossRef] [PubMed]

73. Zhang, H.; Sairam, M.R. Sex hormone imbalances and adipose tissue dysfunction impacting on metabolic syndrome; a paradigm for the discovery of novel adipokines. Horm. Mol. Biol. Clin. Investig. 2014, 17. [CrossRef] [PubMed]

74. von Hafe, P.; Pina, F.; Pérez, A.; Tavares, M.; Barros, H. Visceral fat accumulation as a risk factor for prostate cancer. Obes. Res. 2004, 12, 1930-1935. [CrossRef] [PubMed]

75. Hosgood, H.D.; Gunter, M.J.; Murphy, N.; Rohan, T.E.; Strickler, H.D. The Relation of Obesity-Related Hormonal and Cytokine Levels with Multiple Myeloma and Non-Hodgkin Lymphoma. Front. Oncol. 2018, 8. [CrossRef] [PubMed]

76. Pasquali, R.; Casimirri, F.; De Iasio, R.; Mesini, P.; Boschi, S.; Chierici, R.; Flamia, R.; Biscotti, M.; Vicennati, V. Insulin regulates testosterone and sex hormone-binding globulin concentrations in adult normal weight and obese men. J. Clin. Endocrinol. Metab. 1995, 80, 654-658.

77. Frasor, J.; Danes, J.M.; Komm, B.; Chang, K.C.N.; Lyttle, C.R.; Katzenellenbogen, B.S. Profiling of Estrogen Up- and Down-Regulated Gene Expression in Human Breast Cancer Cells: Insights into Gene Networks and Pathways Underlying Estrogenic Control of Proliferation and Cell Phenotype. Endocrinology 2003, 144, 4562-4574. [CrossRef]

78. Rothenberger, N.; Somasundaram, A.; Stabile, L. The Role of the Estrogen Pathway in the Tumor Microenvironment. Int. J. Mol. Sci. 2018, 19, 611. [CrossRef]

79. Suba, Z. Triple-negative breast cancer risk in women is defined by the defect of estrogen signaling: Preventive and therapeutic implications. Onco. Targets. Ther. 2014, 7, 147. [CrossRef]

80. Zittermann, S.I.; Issekutz, A.C. Basic fibroblast growth factor (bFGF, FGF-2) potentiates leukocyte recruitment to inflammation by enhancing endothelial adhesion molecule expression. Am. J. Pathol. 2006, 168, 835-846. [CrossRef]

81. Itoh, N.; Ohta, H. Pathophysiological roles of FGF signaling in the heart. Front. Physiol. 2013, 4. [CrossRef]

82. Korc, M.; Friesel, R.E. The role of fibroblast growth factors in tumor growth. Curr. Cancer Drug Targets 2009, 9, 639-651. [CrossRef] [PubMed]

83. Chakraborty, D.; Benham, V.; Bullard, B.; Kearney, T.; Hsia, H.C.; Gibbon, D.; Demireva, E.Y.; Lunt, S.Y.; Bernard, J.J. Fibroblast growth factor receptor is a mechanistic link between visceral adiposity and cancer. Oncogene 2017, 36, 6668-6679. [CrossRef] [PubMed]

84. Benham, V.; Chakraborty, D.; Bullard, B.; Bernard, J.J. A role for FGF2 in visceral adiposity-associated mammary epithelial transformation. Adipocyte 2018, 7, 1-8. [CrossRef]

85. Hu, X.; Ma, X.; Luo, Y.; Xu, Y.; Xiong, Q.; Pan, X.; Xiao, Y.; Bao, Y.; Jia, W.-P. Associations of serum fibroblast growth factor 23 levels with obesity and visceral fat accumulation. Clin. Nutr. 2018, 37, 223-228. [CrossRef] [PubMed]

86. Masai, H.; Joki, N.; Sugi, K.; Moroi, M. A preliminary study of the potential role of FGF-23 in coronary calcification in patients with suspected coronary artery disease. Atherosclerosis 2013, 226, 228-233. [CrossRef]

87. Gutiérrez, O.M.; Januzzi, J.L.; Isakova, T.; Laliberte, K.; Smith, K.; Collerone, G.; Sarwar, A.; Hoffmann, U.; Coglianese, E.; Christenson, R.; et al. Fibroblast growth factor 23 and left ventricular hypertrophy in chronic kidney disease. Circulation 2009, 119, 2545-2552. [CrossRef]

88. Hsu, H.J.; Wu, M.-S. Fibroblast growth factor 23: A possible cause of left ventricular hypertrophy in hemodialysis patients. Am. J. Med. Sci. 2009, 337, 116-122. [CrossRef]

89. Ix, J.H.; Katz, R.; Kestenbaum, B.R.; De Boer, I.H.; Chonchol, M.; Mukamal, K.J.; Rifkin, D.; Siscovick, D.S.; Sarnak, M.J.; Shlipak, M.G. Fibroblast growth factor-23 and death, heart failure, and cardiovascular events in community-living individuals: CHS (Cardiovascular Health Study). J. Am. Coll. Cardiol. 2012, 60, $200-207$. [CrossRef]

90. Xiao, Y.; Peng, C.; Huang, W.; Zhang, J.; Xia, M.; Zhang, Y.; Ling, W. Circulating fibroblast growth factor 23 is associated with angiographic severity and extent of coronary artery disease. PLOS ONE 2013, 8, e72545. [CrossRef]

91. Jin, Z.; Liu, Y. DNA methylation in human diseases. Genes Dis. 2018, 5, 1-8. [CrossRef] 
92. Edwards, J.R.; Yarychkivska, O.; Boulard, M.; Bestor, T.H. DNA methylation and DNA methyltransferases. Epigenet. Chromatin 2017, 10, 23. [CrossRef] [PubMed]

93. Nelson, H.H.; Marsit, C.J.; Kelsey, K.T. Global Methylation in Exposure Biology and Translational Medical Science. Environ. Health Perspect. 2011, 119, 1528-1533. [CrossRef]

94. Keller, M.; Hopp, L.; Liu, X.; Wohland, T.; Rohde, K.; Cancello, R.; Klös, M.; Bacos, K.; Kern, M.; Eichelmann, F.; et al. Genome-wide DNA promoter methylation and transcriptome analysis in human adipose tissue unravels novel candidate genes for obesity. Mol. Metab. 2017, 6, 86-100. [CrossRef] [PubMed]

95. Castellano, D.; Moreno-Indias, I.; Sánchez-Alcoholado, L.; Ramos-Molina, B.; Torres, J.A.; Morcillo, S.; Ocaña-Wilhelmi, L.; Tinahones, F.J.; Moreno-Indias, I.; Cardona, F. Altered Adipose Tissue DNA Methylation Status in Metabolic Syndrome: Relationships Between Global DNA Methylation and Specific Methylation at Adipogenic, Lipid Metabolism and Inflammatory Candidate Genes and Metabolic Variables. J. Clin. Med. 2019, 8, 87. [CrossRef]

96. Turcot, V.; Tchernof, A.; Deshaies, Y.; Pérusse, L.; Bélisle, A.; Marceau, S.; Biron, S.; Lescelleur, O.; Biertho, L.; Vohl, M.-C. LINE-1 methylation in visceral adipose tissue of severely obese individuals is associated with metabolic syndrome status and related phenotypes. Clin. Epigenet. 2012, 4, 10. [CrossRef] [PubMed]

97. Hsu, C.-C.; Tseng, L.-M.; Lee, H.-C. Role of mitochondrial dysfunction in cancer progression. Exp. Biol. Med. 2016, 241, 1281-1295. [CrossRef] [PubMed]

98. Lynam-Lennon, N.; Connaughton, R.M.; Carr, E.; Mongan, A.M.; O’Farrell, N.J.; Porter, R.K.; Brennan, L.; Pidgeon, G.P.; Lysaght, J.; Reynolds, J.; et al. Excess visceral adiposity induces alterations in mitochondrial function and energy metabolism in esophageal adenocarcinoma. BMC Cancer 2014, 14, 907. [CrossRef]

99. Vernochet, C.; Damilano, F.; Mourier, A.; Bezy, O.; Mori, M.A.; Smyth, G.; Rosenzweig, A.; Larsson, N.; Kahn, C.R. Adipose tissue mitochondrial dysfunction triggers a lipodystrophic syndrome with insulin resistance, hepatosteatosis, and cardiovascular complications. FASEB J. 2014, 28, 4408-4419. [CrossRef]

100. Li, M.; Cheung, B.M.Y. Pharmacotherapy for obesity. Br. J. Clin. Pharmacol. 2009, 68, 804-810. [CrossRef]

101. Abbas, A.; Blandon, J.; Rude, J.; Elfar, A.; Mukherjee, D. PPAR- $\gamma$ Agonist in Treatment of Diabetes: Cardiovascular Safety Considerations. Cardiovasc. Hematol. Agents Med. Chem. 2012, 10, 124-134. [CrossRef]

102. Corrales, P.; Vidal-Puig, A.; Medina-Gómez, G. PPARs and Metabolic Disorders Associated with Challenged Adipose Tissue Plasticity. Int. J. Mol. Sci. 2018, 19, 2124. [CrossRef] [PubMed]

103. Miyazaki, Y.; Mahankali, A.; Matsuda, M.; Mahankali, S.; Hardies, J.; Cusi, K.; Mandarino, L.; DeFronzo, R. Effect of Pioglitazone on Abdominal Fat Distribution and Insulin Sensitivity in Type 2 Diabetic Patients. J. Clin. Endocrinol. Metab. 2002, 87, 2784-2791. [CrossRef] [PubMed]

104. Lincoff, A.M.; Wolski, K.; Nicholls, S.J.; Nissen, S.E. Pioglitazone and Risk of Cardiovascular Events in Patients with Type 2 Diabetes Mellitus. JAMA 2007, 298, 1180. [CrossRef] [PubMed]

105. Nissen, S.E.; Wolski, K. Rosiglitazone Revisited. Arch Intern Med. 2010, 170. [CrossRef] [PubMed]

106. Vella, V.; Nicolosi, M.L.; Giuliano, S.; Bellomo, M.; Belfiore, A.; Malaguarnera, R. PPAR- $\gamma$ Agonists As Antineoplastic Agents in Cancers with Dysregulated IGF Axis. Front. Endocrinol. (Lausanne) 2017, 8. [CrossRef]

107. Liu, Y.; Jin, P.-P.; Sun, X.-C.; Hu, T.-T. Thiazolidinediones and risk of colorectal cancer in patients with diabetes mellitus: A meta-analysis. Saudi J. Gastroenterol. 2018, 24, 75.

108. Yan, H.; Xie, H.; Ying, Y.; Li, J.; Wang, X.; Xu, X.; Zheng, X. Pioglitazone use in patients with diabetes and risk of bladder cancer: A systematic review and meta-analysis. Cancer Manag. Res. 2018, 10, 1627-1638. [CrossRef]

109. Monami, M.; Dicembrini, I.; Mannucci, E. Thiazolidinediones and cancer: Results of a meta-analysis of randomized clinical trials. Acta Diabetol. 2014, 51, 91-101. [CrossRef]

110. Beauregard, C.; Utz, A.L.; Schaub, A.E.; Nachtigall, L.; Biller, B.M.K.; Miller, K.K.; Klibanski, A. Growth Hormone Decreases Visceral Fat and Improves Cardiovascular Risk Markers in Women with Hypopituitarism: A Randomized, Placebo-Controlled Study. J. Clin. Endocrinol. Metab. 2008, 93, 2063-2071. [CrossRef]

111. Lewitt, M.S. The Role of the Growth Hormone/Insulin-Like Growth Factor System in Visceral Adiposity. Biochem. Insights 2017, 10, 117862641770399. [CrossRef]

112. Livingstone, C.; Borai, A. Insulin-like growth factor-II: Its role in metabolic and endocrine disease. Clin. Endocrinol. 2014, 80, 773-781. [CrossRef] [PubMed]

113. Frühbeck, G. Bariatric and metabolic surgery: A shift in eligibility and success criteria. Nat. Rev. Endocrinol. 2015, 11, 465-477. [CrossRef] [PubMed] 
114. Deodati, A.; Ferroli, B.B.; Cianfarani, S. Association between growth hormone therapy and mortality, cancer and cardiovascular risk: Systematic review and meta-analysis. Growth Horm. IGF Res. 2014, 24, 105-111. [CrossRef] [PubMed]

115. Li, Z.; Zhou, Q.; Li, Y.; Fu, J.; Huang, X.; Shen, L. Growth hormone replacement therapy reduces risk of cancer in adult with growth hormone deficiency: A meta-analysis. Oncotarget 2016, 7. [CrossRef]

116. Maruthur, N.M.; Tseng, E.; Hutfless, S.; Wilson, L.M.; Suarez-Cuervo, C.; Berger, Z.; Chu, Y.; Iyoha, E.; Segal, J.B.; Bolen, S. Diabetes Medications as Monotherapy or Metformin-Based Combination Therapy for Type 2 Diabetes. Ann. Intern Med. 2016, 164, 740. [CrossRef]

117. Pappachan, J.M.; Viswanath, A.K. Medical Management of Diabesity: Do We Have Realistic Targets? Curr. Diab. Rep. 2017, 17, 4. [CrossRef]

118. Tokubuchi, I.; Tajiri, Y.; Iwata, S.; Hara, K.; Wada, N.; Hashinaga, T.; Nakayama, H.; Mifune, H.; Yamada, K. Beneficial effects of metformin on energy metabolism and visceral fat volume through a possible mechanism of fatty acid oxidation in human subjects and rats. PLOS ONE 2017, 12, e0171293. [CrossRef]

119. Zhou, J.; Massey, S.; Story, D.; Li, L. Metformin: An Old Drug with New Applications. Int. J. Mol. Sci. 2018, 19, 2863. [CrossRef]

120. Bailey, C.J. Metformin: Effects on Micro and Macrovascular Complications in Type 2 Diabetes. Cardiovasc. Drugs Ther. 2008, 22, 215-224. [CrossRef]

121. Luo, F.; Das, A.; Chen, J.; Wu, P.; Li, X.; Fang, Z. Metformin in patients with and without diabetes: A paradigm shift in cardiovascular disease management. Cardiovasc. Diabetol. 2019, 18, 54. [CrossRef]

122. Chen, Q.; Thompson, J.; Hu, Y.; Das, A.; Lesnefsky, E.J. Metformin attenuates ER stress-induced mitochondrial dysfunction. Transl. Res. 2017, 190, 40-50. [CrossRef] [PubMed]

123. Saraei, P.; Asadi, I.; Kakar, M.A.; Moradi-Kor, N. The beneficial effects of metformin on cancer prevention and therapy: A comprehensive review of recent advances. Cancer Manag. Res. 2019, 11, 3295-3313. [CrossRef] [PubMed]

124. Campagnoli, C.; Berrino, F.; Venturelli, E.; Abbà, C.; Biglia, N.; Brucato, T.; Cogliati, P.; Danese, S.; Donadio, M.; Zito, G.; et al. Metformin Decreases Circulating Androgen and Estrogen Levels in Nondiabetic Women with Breast Cancer. Clin. Breast Cancer 2013, 13, 433-438. [CrossRef] [PubMed]

125. Yu, H.; Zhong, X.; Gao, P.; Shi, J.; Wu, Z.; Guo, Z.; Wang, Z.; Song, Y.-X. The Potential Effect of Metformin on Cancer: An Umbrella Review. Front. Endocrinol. (Lausanne) 2019, 10. [CrossRef] [PubMed]

126. Colotta, F.; Allavena, P.; Sica, A.; Garlanda, C.; Mantovani, A. Cancer-related inflammation, the seventh hallmark of cancer: Links to genetic instability. Carcinogenesis 2009, 30, 1073-1081. [CrossRef] [PubMed]

127. Farb, M.G.; Tiwari, S.; Karki, S.; Ngo, D.T.; Carmine, B.; Hess, D.T.; Zuriaga, M.A.; Walsh, K.; Fetterman, J.L.; Hamburg, N.M.; et al. Cyclooxygenase inhibition improves endothelial vasomotor dysfunction of visceral adipose arterioles in human obesity. Obesity 2014, 22, 349-355. [CrossRef] [PubMed]

128. Antman, E.M.; Bennett, J.S.; Daugherty, A.; Furberg, C.; Roberts, H.; Taubert, K.A. Use of Nonsteroidal Antiinflammatory Drugs. Circulation 2007, 115, 1634-1642. [CrossRef]

129. Cannon, C.P.; Cannon, P.J. COX-2 Inhibitors and Cardiovascular Risk. Science 2012, 336, 1386-1387. [CrossRef]

130. Gurpinar, E.; Grizzle, W.E.; Piazza, G.A. COX-Independent Mechanisms of Cancer Chemoprevention by Anti-Inflammatory Drugs. Front. Oncol. 2013, 3. [CrossRef]

131. Chow, L.W.C.; Loo, W.T.Y.; Toi, M. Current directions for COX-2 inhibition in breast cancer. Biomed. Pharmacother. 2005, 59, S281-S284. [CrossRef]

132. Tóth, L.; Muszbek, L.; Komáromi, I. Mechanism of the irreversible inhibition of human cyclooxygenase-1 by aspirin as predicted by QM/MM calculations. J. Mol. Graph. Model. 2013, 40, 99-109. [CrossRef] [PubMed]

133. Ornelas, A.; Zacharias-Millward, N.; Menter, D.G.; Davis, J.S.; Lichtenberger, L.; Hawke, D.; Hawk, E.; Vilar, E.; Bhattacharya, P.; Millward, S. Beyond COX-1: The effects of aspirin on platelet biology and potential mechanisms of chemoprevention. Cancer Metastasis Rev. 2017, 36, 289-303. [CrossRef] [PubMed]

134. Alenghat, F.J.; Davis, A.M. Management of Blood Cholesterol. JAMA 2019, 321, 800. [CrossRef] [PubMed]

135. Oesterle, A.; Laufs, U.; Liao, J.K. Pleiotropic Effects of Statins on the Cardiovascular System. Circ. Res. 2017, 120, 229-243. [CrossRef]

136. Katsiki, N.; Mantzoros, C.S. Statins in relation to adiponectin: A significant association with clinical implications. Atherosclerosis 2016, 253, 270-272. [CrossRef] 
137. Raggi, P.; Gadiyaram, V.; Zhang, C.; Chen, Z.; Lopaschuk, G.; Stillman, A.E. Statins Reduce Epicardial Adipose Tissue Attenuation Independent of Lipid Lowering: A Potential Pleiotropic Effect. J. Am. Heart Assoc. 2019, 8. [CrossRef]

138. Singh, S.; Singh, A.G.; Singh, P.P.; Murad, M.H.; Iyer, P.G. Statins Are Associated With Reduced Risk of Esophageal Cancer, Particularly in Patients With Barrett's Esophagus: A Systematic Review and Meta-analysis. Clin. Gastroenterol. Hepatol. 2013, 11, 620-629. [CrossRef]

139. Liu, Y.; Tang, W.; Wang, J.; Xie, L.; Li, T.; He, Y.; Deng, Y.; Peng, Q.; Li, S.; Qin, X. Association between statin use and colorectal cancer risk: A meta-analysis of 42 studies. Cancer Causes Control 2014, 25, 237-249. [CrossRef]

140. Singh, P.P.; Singh, S. Statins are associated with reduced risk of gastric cancer: A systematic review and meta-analysis. Ann. Oncol. 2013, 24, 1721-1730. [CrossRef]

141. Yang, J.; Li, C.; Shen, Y.; Zhou, H.; Shao, Y.; Zhu, W.; Chen, Y. Impact of statin use on cancer-specific mortality and recurrence. Medicine (Baltimore) 2020, 99, e19596. [CrossRef]

142. Mansourian, M.; Haghjooy-Javanmard, S.; Eshraghi, A.; Vaseghi, G.; Hayatshahi, A.; Thomas, J. Statins Use and Risk of Breast Cancer Recurrence and Death: A Systematic Review and Meta-Analysis of Observational Studies. J. Pharm. Pharm. Sci. 2016, 19, 72. [CrossRef] [PubMed]

143. Phan, B.A.P.; Dayspring, T.D.; Toth, P.P. Ezetimibe therapy: Mechanism of action and clinical update. Vasc. Health Risk Manag. 2012, 8, 415. [PubMed]

144. Takase, H.; Dohi, Y.; Okado, T.; Hashimoto, T.; Goto, Y.; Kimura, G. Effects of ezetimibe on visceral fat in the metabolic syndrome: A randomised controlled study. Eur. J. Clin. Investig. 2012, 42, 1287-1294. [CrossRef] [PubMed]

145. Dolezelova, E.; Stein, E.; Derosa, G.; Maffioli, P.; Nachtigal, P.; Sahebkar, A. Effect of ezetimibe on plasma adipokines: A systematic review and meta-analysis. Br. J. Clin. Pharmacol. 2017, 83, 1380-1396. [CrossRef] [PubMed]

146. Zhan, S.; Tang, M.; Liu, F.; Xia, P.; Shu, M.; Wu, X. Ezetimibe for the prevention of cardiovascular disease and all-cause mortality events. Cochrane Database Syst. Rev. 2018. [CrossRef] [PubMed]

147. Miura, K.; Ohnishi, H.; Morimoto, N.; Minami, S.; Ishioka, M.; Watanabe, S.; Tsukui, M.; Takaoka, Y.; Nomoto, H.; Isoda, N.; et al. Ezetimibe suppresses development of liver tumors by inhibiting angiogenesis in mice fed a high-fat diet. Cancer. Sci. 2019, 110, 771-783. [CrossRef]

148. Masko, E.M.; Alfaqih, M.A.; Solomon, K.R.; Barry, W.T.; Newgard, C.B.; Muehlbauer, M.J.; Valilis, N.A.; Phillips, T.E.; Poulton, S.H.; Freedland, A.R.; et al. Evidence for Feedback Regulation Following Cholesterol Lowering Therapy in a Prostate Cancer Xenograft Model. Prostate 2017, 77, 446-457. [CrossRef]

Publisher's Note: MDPI stays neutral with regard to jurisdictional claims in published maps and institutional affiliations.

(C) 2020 by the authors. Licensee MDPI, Basel, Switzerland. This article is an open access article distributed under the terms and conditions of the Creative Commons Attribution (CC BY) license (http://creativecommons.org/licenses/by/4.0/). 